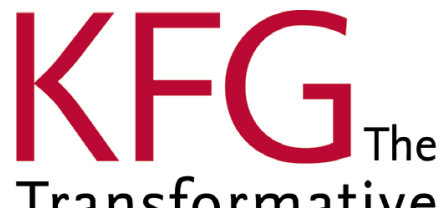

Transformative Power of Europe

Networks, Courts and Regional Integration

Explaining the Establishment of the Andean Court of Justice

Osvaldo Saldías

No. 20 | November 2010 


\section{KFG Working Paper Series}

\section{Edited by the Kolleg-Forschergruppe "The Transformative Power of Europe"}

The KFG Working Paper Series serves to disseminate the research results of the Kolleg-Forschergruppe by making them available to a broader public. It means to enhance academic exchange as well as to strengthen and broaden existing basic research on internal and external diffusion processes in Europe and the European Union.

All KFG Working Papers are available on the KFG website at www.transformeurope.eu or can be ordered in print via email to transform-europe@fu-berlin.de.

Copyright for this issue: Osvaldo Saldías

Editorial assistance and production: Julia Stark, Corinna Blutguth

Saldías, Osvaldo 2010: Networks, Courts and Regional Integration.Explaining the Establishment of the Andean Court of Justice, KFG Working Paper Series, No. 20, November 2010, Kolleg-Forschergruppe (KFG) "The Transformative Power of Europe", Freie Universität Berlin.

ISSN 1868-6834 (Print)

ISSN 1868-7601 (Internet)

This publication has been funded by the German Research Foundation (DFG).

Freie Universität Berlin

Kolleg-Forschergruppe

„The Transformative Power of Europe:

The European Union and the Diffusion of Ideas“

Ihnestr. 26

14195 Berlin

Germany

Phone: +49 (0)30- 83857033

Deutsche

Fax: +49 (0)30- 83857096

transform-europe@fu-berlin.de 


\title{
NetWORKS, COURTS AND REgIONAL INTEGRATION \\ EXplaining the Establishment Of the AndeAn COURT OF JUSTICE
}

\author{
Osvaldo Saldías \\ Freie Universität Berlin
}

\begin{abstract}
Legal transplants have traditionally been believed to be the product of reason and informed decisionmaking that follow arduous deliberations and bargaining between lawmakers. This paper argues that some major legal transformations can be better explained with the help of networks. It delves into the history of the establishment of the Andean Court of Justice and asks who got to decide the major questions in regard to the institutional design of the court. I argue that contrary to dominant assumptions, consultants and think tanks play a decisive role in the shaping of legal transplants. They are the ones that decide which model to follow. They get to choose participants in relevant working groups and it is them who shape the final proposal that will be voted by the lawmaker. As the complexity of the topic increases, professional networks can use technical discourse that makes scrutiny unlikely. The research shows that in case of Andean regional integration, the personal background of consultant is also very relevant, because it determines what models will be considered for eventual benchmarking. However, the mere existence of networks is not enough for producing legal change; a window of opportunity is a necessary condition.
\end{abstract}

\section{The Author}

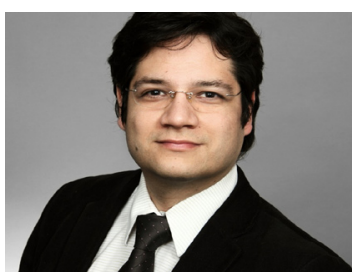

Osvaldo Saldías is post-doctoral fellow at the Research College "The Transformative Power of Europe". His research interest covers comparative regionalism, European integration and Law \& Politics. He is an admitted Chilean lawyer and wrote his PhD thesis at the Freie Universität Berlin. Contact: osaldias@zedat.fu-berlin.de 


\section{Contents}

1. Introduction 5

2. The Transplant Approach and the Andean Puzzles 5

2.1 Aims and Limitations of the Transplant Approach 5

2.2 Three Andean Puzzles $\quad 7$

3. Epistemic Communities and Advocacy Coalitions: A Framework 9

$\begin{array}{ll}\text { 4. The Andean-European Network } & 11\end{array}$

4.1 Crafting a Policy Core for the Network 11

$\begin{array}{ll}4.2 \text { Diffusing the Network's Policy Program } & 14\end{array}$

5. Conditions for the Action of Networks: Using Windows of Opportunities 14

6. Contesting the Governments' Control over the Integration Process 16

6.1 The Case of the Chilean Parliament 16

6.2 Colombia and its Supreme Court 16

7. Expanding the Network: Bringing the Judges in 18

8. Conclusion 20

$\begin{array}{ll}\text { Literature } & 22\end{array}$ 


\section{Introduction ${ }^{1}$}

It is no secret that most legal reforms have borrowed much from other legal systems. It is a mystery though, how these processes come about. In other words, we do not know who gets to decide what solution and from where it should be taken. The case of the Andean Community and the transplantation of the European Court of Justice (EJC) along with the whole judicial system raise these kinds of questions. This paper tries to complement the literature on diffusion of European ideas as well as the legal transplant approach. I argue that network analysis offers a nuanced explanation of legal transformation. The search for the model is determined not only by legitimacy, but by personal linkages within a network and the professional background of its members. In addition, professional networks tend to frame problems as technically as possible in order to further their policy agenda as much as possible. However, the mere existence of networks is not sufficient for provoking legal-institutional change. As the case of the EuropeanAndean networks shows there must be enabling conditions that allow networks to accommodate existing preferences by proposing technical solutions that satisfy governments' needs, as well as their own professional agenda.

The article is divided into six sections. Sections 1 and 2 establish the theoretical framework and point to three puzzles that drive this work. Sections 3 and 4 contain the empirical data found in the history of the establishment of the Andean Court of Justice (ACJ). It focuses on the mechanism found in the process of legal transformation and on the role of professional legal networks. Section 5 gives an account of the expansion of these networks and the impact that they had on the actual case law handed down by the Court.

\section{The Transplant Approach and the Andean Puzzles}

\subsection{Aims and Limitations of the Transplant Approach}

The term "legal transplant" has been among us for some time and has spurred interesting discussions. ${ }^{2}$ However, we still do not know what it exactly means. It seems to be clear though, that legal scholars seem to have divergent understandings of what a legal transplant is. The most prominent literature on legal transplants stresses the diffusion of law, principles, and societal beliefs from one legal system to another (Watson 1993; Horwitz 2009). Such transfers of law can be observed throughout human history, especially in times of imperial expansion, colonialism, and enlightenment. Notwithstanding the numerous cases that can be observed, the transplant approach is still very limited. Scholars using this approach are largely unable to explain why similar transplants do not produce similar results or why legal transplants tend to change over time. There are, nevertheless, some valuable attempts.

1 This paper results from research conducted at the at the Kolleg-Forschergruppe (KFG) "The Transformative Power of Europe," hosted at the Freie Universität Berlin (www.transfromeurope.eu). I would like to thank Karen Alter, Thomas Ghering, Anja Jetschke for their helpful comments. I am also indebted to the KFG Kolleg-Forschergruppe, especially the participants of the Jour Fixe, whose comments helped me improve this working paper, as well as to Marianne van de Steeg for her permanent friendly advice. All errors remain my own.

2 For instance, the last volume (July) of Theoretical Inquiries in Law (2009) is "made up of studies of histories of legal transplantations". In addition, a long-lasting debate about the theoretical robustness of the legal transplant approach has not been settled yet (see Legrand 1997; cf. Watson 2000). 
Some scholars have suggested that certain legal traditions - or legal families - have immanent qualities that determine or predict adaptation in a new environment; many contend that transplanting Common Law systems produces higher levels of legality in the host system than transplanting norms from Civil Law systems (e.g. La Porta et al. 1998; Mahoney 2001). In addition, recent literature links the performance of legal transplants with the ability of the recipient legal community to internalize the rules, principles, and values of the donor system (Berkowitz et al. 2003: 179). It is thereby assumed that successful internalization of new norms depends on the inherent abilities of either the donor - also called origin - or the recipient legal order. Moreover, these theories share the assumption that the only interaction that takes place occurs among legal systems. This literature is not acknowledging however, some important circumstances about the transplant approach. First, the transplant approach is not a theory; at least not yet. Writers have not yet come up with any system of causal links or analytical explanations. It is not a normative theory either because it lacks a core of values that could be regarded as the genesis of a principled discourse. Second, the transplant approach is not a method. Scholars have failed to analyze legal transplants according to any consensual proceeding that would allow the establishment of hypotheses. Until this happens, it will be very difficult to falsify any claim on legal transplants.

When we talk about legal transplants, we refer to an approach based on a metaphor (Nelken 2001). It helps us to think about diffusion of law in creative ways. It is very helpful to depict the process of legal transformation in terms of a donor and a recipient. As a metaphor, legal transplants provide a heuristic frame, within which scholars can use a wide range of analytical toolkits. Interdisciplinary research is only one possible way of combining the transplant metaphor with middle-range theories.

Political scientists, for instance, are increasingly including the study of legal transplants in their research agendas, especially as a dimension of policy transfer and norm diffusion (see for instance Börzel/Risse 2009). The central question is how the process of transplantation comes about. Law cannot transport itself. There are mechanisms and actors that are responsible for the process of diffusion. Following these questions, some writers focus on the agency that the phenomenon of transplantation is associated with. According to them, legal experts are frequently agents of transplantation that advocate for the transplantation of well functioning legal systems and swarm developing countries with constitutions, codes, statutes, and regulations (Berkowitz et al. 2003: 164; also called "entrepreneurial transplants" by Likhovski 2009: 621). So far, there has not been an explanation about who these experts are and how the mechanisms for the diffusion of legal institutions work.

In this article, I use the transplant metaphor as a heuristic frame for gauging the mechanisms for the diffusion of legal institutions. Within this frame, there are several processes of diffusion carried out by different groups of actors, each of them following a particular logic of action. I examine how actors coordinate their action through networks and advocate for a distinctive institutional outcome: the adoption of legal institutions from another region. Finally, I inquire about the conditions under which networks can achieve their goals of transplanting legal institutions from one setting to another. In this way, this research aims to becoming a contribution to the literature of diffusion of ideas and institutions, regional integration, and of course, the comparative law's literature on legal transplants. ${ }^{3}$

3 The implications of the Andean Court of Justice and its case law for the process of regional integration, as well as the differences with the European Court of Justice (ECJ) are discussed elsewhere (see Saldías 2007; Helfer et al. 2009). 


\subsection{Three Andean Puzzles}

In May 1969, the Andean states Bolivia, Chile, Colombia, Ecuador, and Peru signed the Cartagena Agreement, commonly known as the "Andean Pact". ${ }^{4}$ The main goal of the Cartagena Agreement was the establishment of a common market in the region. Despite an initial optimism, by the end of the 1970 s this regional organization was still far from its goal. The reason was allegedly the endemic non-compliance with community rules, especially those establishing deadlines for the dismantling of trade barriers (JUNAC 1979: 12, 84; Hurtado Larrea 1985: 72f; JUNAC 1983; Perotti 1999: 193). Like many other Latin American arrangements, the Andean Pact seemed to be stuck in the process of integration.

In the late 1970s and early 1980s, the process of regional integration in South America was reinvigorated. The Southern Common Market MERCOSUR saw the light, ${ }^{5}$ and the Andean Pact underwent significant transformations. Specifically, in 1979, the Andean main intergovernmental and legislative body, the Commission, ${ }^{6}$ approved a proposal for the establishment of a supranational Court of Justice in the image of the ECJ. ${ }^{7}$ This meant that EC law and EC judicial remedies were to be transplanted into the Andean Pact in one of the most striking action of legal diffusion in the history of South American republics.

It is precisely at this point where most of the literature on the Andean Court of Justice begins. ${ }^{8}$ The establishment of the Court is often presented in the literature as a fait accompli, which does not need further elaboration about the process of legal reform. However, the fact that a rather controversial judicial institution like the ECJ could be transplanted with so little mutations is utterly intriguing and it should be researched further. It is unclear why scholars of regional integration have not noticed that such phenomena are not necessarily natural to international organizations.

Moreover, the literature on the Andean integration and Andean law has persistently neglected an important fact: already in 1972, the Andean Commission - the organization's major decision-making body - had manifested the necessity of creating a dispute settlement body. During one of its summits, it instructed the Junta - to a great extent the Andean executive organ - to present a report (henceforward "the report") with a concrete recommendation on this matter (Andean Commission 1971). For the diffusion theory, this is puzzling. The Commission's mandate to the Junta came only three years after the establishment of the Cartagena Agreement. The most recurrent explanations point to functional requirement already

4 Chile withdrew on October 30th 1976 and Venezuela joined in February 13th 1973, only to withdraw again in 2006.

5 Inspired in the European Community (EC), the Andean System of Integration was established on March 10th by the Trujillo Protocol. It is important to note that the Andean Pact was renamed Andean Community. MERCOSUR was established by the Treaty of Asunción on March 26th 1991.

6 Readers familiar with EU studies might find the names of the Andean organs confusing. Contrary to the EC, the Andean Commission is the intergovernmental body composed by member states representatives. Until 1997 the Andean executive organ comparable to the European Commission, was the Junta of the Cartagena Agreement (today the General Secretariat of the Andean Community).

7 For a thorough overview of the legal and institutional reform that transformed the Andean Pact into the Andean Community, see Marwege 1995.

8 Just as an example of noted work on the subject: Andueza 1986; da Cruz Vilaça/Sobrino 1996; Ekmekdjian 1994; Sáchica 1985a; Suárez Mejías 2001; Tangarife 2001b. 
mentioned above: the search for a solution to endemic non-compliance. In general, this contention is plausible. However, it fails to answer three important questions:

First, how could the Commission come to the conclusion that there was a compliance problem serious enough to justify a judicial body in less than three years? The Cartagena Agreement included the possibility of using the dispute settlement system of Latin American Free Trade Association, LAFTA (Zelada Castedo 1985: 126). What explains the possible dissatisfaction with a system that had not been used even once?

Second, Latin American states have a strong tradition in respecting national sovereignty (Salazar Santos 1973a: 5). Conflicts have traditionally been solved through discrete negotiations between the parties (Paolillo/Ons-Indart 1971) and the prevailing style for international coordination has been consensus at the highest political level; in Latin American jargon: Concertación (Emmes/Mols 1993: 69). Moreover, when it comes to economic processes there is a known resistance to including lawyers and judges. It is assumed that these professionals frequently lead such dynamic developments to a paralysis. ${ }^{9}$ What could have driven the member states to break with this tradition only three years after the Cartagena Agreement was negotiated?

Third, why did the Andean Group establish a court so similar to the European Court of Justice? This puzzle is even more intriguing considering the dominance of the principles of Concertación and sovereignty in Latin America.

The findings presented below suggest that the Andean governments faced serious resistance when they tried to incorporate the Founding Treaty, this is, the Cartagena Agreement into the national order. The cases of the Chilean Parliament and the Colombian Supreme Court show how these actors challenged their governments and contested their powers to control the process of regional integration. Although the governments could finally accomplish their task, it came at a very high cost: the political and legal control of the process had to be shared with other national actors. This scenario of legal contestation laid the conditions for the action of professional networks, because member states' governments were willing to cede some sovereignty to a court as long as it would mitigate the growing domestic demand for control. The network, in turn, had a record advocating for the establishment of a judicial organ in the integration process and used the opportunity to frame the problems of the organization as a strict technical-legal matter. Moreover, the network was heavily biased towards Europe, which suggests that the drafters of the final report used mainly European informational resources to look for a solution and to shape their proposal.

9 Although there is no study that offers conclusive evidence, there seems to be a consensus among scholars that this is true (see Padilla 1979: 91; Orrego Vicuña 1973: 135, 1974: 31). 


\section{Epistemic Communities and Advocacy Coalitions: A Framework}

It is a truism to say that the emergence and diffusion of laws depend on reasons that sometimes transcend pure normative criteria. Nevertheless, the traditional literature of comparative law tends to focus more on legal institutions than on the social implications of law (see e.g. Zweigert/Kötz 1996). The underlying juridical assumption in the traditional literature is that law - and law alone - shapes reality. As a consequence, the processes that change these institutions or the actors that shape them are underresearched topics. Following a strand that is closer to socio-legal studies, I claim that network analysis can contribute to the understanding of legal transplants, to its emergence, its implementation, and its evaluation, because it can causally link actors and facts that precede the transplant's outcome. The existence, incorporation, and performance of legal norms depend not only on the law itself but also on a variety of actors that participate in the legal process at different stages. These actors are interested in the outcomes of transplants and interact in complex patterns. The transplantation process originates a multitude of coordinated behavior and interdependencies of a wide array of types and pushes existing typologies to their limits (for a review of the different policy network concepts, see Börzel 1997).

The literature on networks offers some frameworks that are very helpful to gauge the actors that are relevant in the process of a legal transplant. For instance, the Advocacy Coalition Framework (JenkinsSmith/Sabatier 1994; Zafonte/Sabatier 1998) portrays the process of institutional change produced by groups of actors that share a policy interest and have common beliefs about norms and institutions. This constitutes their common policy core and it holds them together just like "glue" (Zafonte/Sabatier 1998: 477). In the case of professionals, the common academic background and socialization can bring them together into networks and spur coordinated action towards specific policy goals. This framework introduces new insights into the process of legal change because it includes various institutions participating in the decision-making process into the analysis, as well as different levels of the law-making process. ${ }^{10}$ This focus deviates from traditional institutionalism because it expects any institutional or legal change to be channeled through the legal profession instead of the institutions themselves. It is the members of the profession who act as rationalizers and push for change (DiMaggio/Powell 1983). ${ }^{11}$

Parallel to the Advocacy Coalition Framework, some scholars focus on epistemic communities and their role in international policy coordination. Peter Haas defined them as "networks of knowledge-based experts" and assumed that their members were primarily interested in knowledge and in understanding the world according to analytic or scientific methods. The procedures for acquiring this knowledge would validate their output and distinguish them from an ordinary interest group (Haas 1992: 2, 16). For this literature, the relevance of epistemic communities lies in their ability to understand problems of high complexity and give advice to decision-makers. Sometimes their output can even help states identify their interests. This means that the ways in which states and organizations identify their problems and try to solve them are functions of how problems are understood by policy-makers themselves or by whom they turn for advice. The logic of epistemic policy coordination, then, begins to unveil due to an initial

10 Originally, Zafonte and Sabatier focused on policymaking instead of law-making and also on different institutions within the government.

11 DiMaggio and Powell made this claim when they referred to the process of homogenization within an epistemic field (see DiMaggio/Powell 1983: 147). 
uncertainty on how to solve problems; this uncertainty is likely to become more salient as complexity of issues rises (Haas 1992: 3, 12). ${ }^{12}$ Therefore, epistemic communities can influence policy-making by identifying relevant problems and proposing solutions. Nonetheless, epistemic communities are strongly committed to the same episteme that unites them. This means that, unlike other interest groups, they would withdraw from the policy debate after consistent evidence proved their causal beliefs to be wrong (“anomalies" in Haas' words; Haas 1992: 18).

On a closely related strand, organization theorists have also examined the role that uncertainty plays in processes of diffusion. They suggest that organizations "tend to model themselves after similar organizations in their field that they perceive to be more legitimate or successful" (DiMaggio/Powell 1983: 152). Consistent with our network approach, members of epistemic networks will advocate for the implementation of solutions found in successful organizations primarily because there is more information available, there are more resources and because it provides increased legitimacy. According to DiMaggio and Powell uncertainty only exacerbates such pressure; hence their hypothesis reads "the more uncertain the relationship between means and ends the greater the extent to which an organization will model itself after organizations it perceives to be successful" (DiMaggio/Powell 1983: 154; Zucker 1987: 443). The modeling that takes place begins with formal structures that are emulated.

The findings in this article will be interpreted in this light. The assumptions and causal mechanism are certainly not identical in the three approaches. Sometimes they knock themselves out, at least partially. They are, however, very useful tools to assess my puzzles and give orientations to the research questions. The Andean narrative on the establishment of its Court of Justice shows that focusing on networks across institutions offers a plausible account of the reasons that led Andean decision-makers to transplant an entire court of justice. At some points, though, when applied to the Andean case, the different frameworks tend to overlap and it becomes unclear whether the observable networks are epistemic communities, advocacy coalitions, or just organizations mimicking other organizations. The Andean network features many traits of epistemic communities; but its behavior seems to be more consistent with the advocacy coalitions. Similarly, the documentation analyzed here suggests that the European Court of Justice has always been a highly regarded institution. Nevertheless, there are strong reasons to believe that the causal mechanism was not mimicry, but rational bargaining between the network and national governments under very special enabling conditions of domestic contestation.

12 "Poorly understood conditions may create enough turbulence that established operating procedures may break down, making institutions unworkable. Neither power nor institutional cues to behavior will be available, and new patterns of action may ensue." (Haas 1992: 14) 


\section{The Andean-European Network}

\subsection{Crafting a Policy Core for the Network}

The Junta conducted its research with significant assistance from the Institute for the Integration of Latin America and the Caribbean (INTAL) established by the Inter-American Development Bank in 1965. INTAL's headquarters are located in Buenos Aires and its mission is "to promote and consolidate Latin American and Caribbean integration at the sub-regional, regional, inter-regional, hemispheric and international levels". ${ }^{13}$ Among other tools, the institute achieves this goal by means of technical assistance and capacity building activities for the formulation and enforcement of integration policies. INTAL is also an agent for dissemination of knowledge in the field of regional integration with an explicit focus on Europe. This task was undertaken by means of several periodicals that were published and financed by the institute, notably Revista Integración Latinoamericana, Derecho de la Integración, Revista de la Integración, and the Serie Publicaciones INTAL. ${ }^{14}$ During the time between the discussion and establishment of the Andean Court of Justice, the work of distinguished international scholars was translated and published in INTAL's periodicals including: Ernst Haas (1972), Bela Balassa (1972), Joseph Nye (1969), Philippe Schmitter (1969), Maurice Lagrange (1968), and Pierre Pescatore (1967). Although the institution sees itself as an academic research centre, it might very well be analyzed as a policy-oriented institution, with a clear mandate that is not questioned nor scrutinized by its members. In other words, it has a clear bias towards regional integration.

Following the Commission's mandate, the Junta set up a working group ("the working group") that would meet several times within a short period of time. As I show in this research, the participants of that group are very relevant to the outcome of the deliberations on the Andean Court of Justice and they constituted an active network of scholars and officials (also "INTAL-Junta Network). Felix Peña was at that time a senior consultant at INTAL and directed by the institute's department for legal studies. ${ }^{15}$ Felix Peña's academic background is strongly tied to European studies and European legal integration. Born in Argentina, he earned a degree in European law in Leuven and had written his dissertation at the Law School of the University of Madrid. In regard to European integration theorists, it is worthy to note that he worked under supervision of Ernst Haas at the University of Berkeley in $1973 .{ }^{16}$ During the time between 1966 and 1975, he directed the department of legal studies of INTAL. Some evidence shows that comparative ideas analysis about the ECJ and an eventual Andean Court were discussed by Peña and some collaborators as early as 1971. In March of that year, Peña and Francisco Orrego Vicuña, a Chilean law professor and one of the consultants to INTAL, participated in a colloquium on the "Legal Aspects of

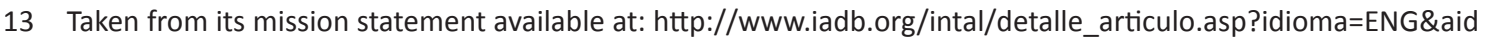
$=490 \&$ cid=206\&nivel=>; last access 18 August 2010 .

14 All of them ceased to be published. Revista Integración Latinoamericana was published from 1976-1995, Derecho de la Integración from 1967-1978, Revista de la Integración from 1967-1975, Serie Publicaciones INTAL from 1964-1996. They were replaced by other periodicals that are equally devoted to the topic of regional integration, like for instance, Revista Integración \& Comercio, which saw the light in 1996.

15 Two years later he would become Director of INTAL and vice-manager (subgerente) of Integration at the InterAmerican Development Bank.

16 All information taken from his CV available at: http://www.felixpena.com.ar/index.php?contenido=trayectoria; last access 18 August 2010. 
Economic Integration" organized by the Hague Academy of International Law. Orrego Vicuña had the task of presenting the Latin American experience with integration. This event gave both the opportunity to meet their European colleagues, especially those concerned with the role of the European Court of Justice. Among the participants in that colloquium was the ECJ Judge Roberto Monaco, as well as Eric Stein from the University of Michigan. The event had a strong comparative perspective and accordingly, several reports were presented for the cases of the European Communities, East Europe, and Africa. Orrego Vicuña's report focused on the necessity of a judicial body that could strengthen the processes of integration in Latin America, especially in the light of the ambitious goals. The edited volume that resulted incorporates the oral intervention of the participants (see Rideau 1973). One interesting intervention belongs to Eric Stein who makes a comparison between the regions, making "a scale according to a degree of intimacy of the symbiotic relationship between the integration law and the national legal system" (Rideau 1973: 465f). In his comparison, Stein locates the Andean Pact far away from the European Communities, mainly because of the deciding role that the ECJ played in Europe through the Article 177 of the Treaty of the European Community (EC). It is fair to note that Stein makes this exercise rather reluctantly in an academic environment, also admitting that he is not an expert in fields other than European Law. Nevertheless, this experience indicates that the INTAL network was familiar with the ECJ as early as $1971 .{ }^{17}$ Soon after this event, the INTAL periodical Derecho de la Integración published and translated articles of Maurice Lagrange (1968) and Pierre Pescatore (1967). Furthermore, one of the Editorials in 1971, although not signed by Peña, sets the foundations for the document that would be incorporated into the Junta's final report for the Commission (see INTAL 1971: 5).

It was planned for the report to include different elements. First, experts' opinions were commissioned for two core issues. One related to the regional dimension of law and the judiciary and was assumed by INTAL scholars. Felix Peña himself delivered an opinion on alternatives for a dispute settlement system within an integration scheme and Francisco Villagrán Kramer prepared a second opinion on the need of legal control of Andean administrative acts. Villagrán Kramer was part of the INTAL team too; prior to the assignment he had written in Derecho de la Integración about legal instrument of Central American integration (Villagrán Kramer 1968). The third INTAL consultant was Felipe Paolillo, a scholar from University of Montevideo, who had equally presence in the journal (Paolillo 1968). Furthermore, national specialists from each member state briefed the Junta about the validity of rulings and awards of international tribunals within their national legal traditions. Among these national experts were Jacobo Schaulson from Chile and Jaime Vidal Perdomo from Colombia. ${ }^{18}$ Having collected the material, the Junta called for an experts' meeting on June 23rd, 1972, bringing together all the authors mentioned above. In addition, two European officials were invited to that summit, in order to provide insights from the European experience: the European Commission's acting director of the Legal Service, Gerard Olivier, as well as ECJ judge Pierre Pescatore (Marwege 1995: 71-2), together with the scholars that had delivered the opinions and the briefings.

The report also includes the content of a conference organized by the Secretariat of the Central American Common Market on the issue "dispute settlement in integration arrangements", where representatives

17 Interestingly, Felix Peña attempts an argument that stresses the trait of Concertación within the judicial function. Although acknowledging the control function of the judiciary, his tone is rather sceptical of radical jurisdiction in Latin America; a line of thought that would markedly change after this event (see his opinion in the report).

18 Also attending that particular meeting: Renato Crespo (Bolivia), Ramiro Borja y Borja (Ecuador) and Hector Cornejo Chavez (Peru). 
of the Junta converged with experts like Walter Much, General Director of the European Commission's Legal Service, as well as Maurice Lagrange, General Advocate of the ECJ; in addition, the report states that two representatives of the Junta were invited to Luxembourg and Brussels in order to gain insights on the functioning of the ECJ and its legal system (JUNAC 1972: 135).

All over the text of the report, there are short references to the participant's individual contribution, which converge into one major policy recommendation. Those contributions were also collected and published by INTAL in two issues of Derecho de la Integración.

An examination of all contributions suggests that it was not intended by the working group to design a new dispute settlement mechanism from scratch. It was rather a preliminary introduction of five prototypes that appeared as possible candidates, namely the Latin American Free Trade Association (LAFTA), the Central American Common Market (CACM), the European Community, the Economic Community of West African States (ECOWAS), and the General Agreement on Tariffs and Trade (GATT). Yet, the report is strongly biased in favor of the European Court of Justice. The INTAL consultants make constant references to the European experience and most of them are laudatory remarks (see e.g. INTAL 1972: 123, 6; also JUNAC 1973: 139, 40, 41, 46). Conversely, references to the system of LAFTA are tainted with a rather skeptical tone, ${ }^{19}$ probably because it was the model that was being questioned. It seems that Felix Peña's argument shapes the entire reading of the report. In his contribution, he makes an abstract claim that integration schemes are to be classified into complex and non-complex systems. It follows, that non-complex integrations schemes may use less institutionalized dispute settlement mechanisms like mediation. Conversely, complex arrangements should have highly institutionalized jurisdictional bodies. Although Peña refrains from making a bold personal policy recommendation, it is quite clear what he meant, because the Andean Pact - and its successor the Andean Community - claimed to be one of the most sophisticated systems next to the European Community. That Peña's typology permeated the whole report can be upheld because he was the designated director of the working group.

Therefore, the outcome of the report is not a surprise. The Junta presents a blueprint for a court, armored with procedures of nullification, non-compliance, and preliminary rulings; all three procedures flanked by the doctrine of supremacy of supranational law (JUNAC 1973: 139, 49f). ${ }^{20}$ The report is formally approved by the Commission in December 1972, and the main meeting's protocol records a brief passage referring to a "wide exchange of opinions" that supposedly took place, followed by the expression of "satisfaction on how the Junta has been conducting its work". ${ }^{21}$ As a result, the Junta agreed to present a final proposal and to assist member states in the task of diffusing and explaining the meaning of its report.

19 "El sistema de solución de controversias establecido en la ALALC no satisface los requisitos que acabamos de apuntar" (JUNAC 1973: 144).

20 It is interesting to note that the paragraph that justifies the need for Andean law's supremacy over domestic law, quotes "the president of the European Court of Justice" - by that time Robert Lecourt.

21 "La presentación del informe dio lugar a un amplio intercambio de opiniones de carácter preliminar, que permitió a la Junta dar explicaciones adicionales sobre el proyecto de bases de tratado que ha elaborado y escuchar las reacciones iniciales de las Representaciones en torno a este tema. Las Representaciones reiteraron la importancia de contra en la Subregión con un instrumento de esta naturaleza y su conformidad con la manera en que la Junta viene desarrollando estos trabajos" (Andean Comisión 1972: 3; emphasis added). I am grateful to Mrs. Zoila Choque Domenique, Documentation Centre of the Andean Community, for her helping me accessing these rare documents. 


\subsection{Diffusing the Network's Policy Program}

The fact the INTAL-Junta network was very aware of the importance of diffusion can be inferred from its regional activities. After the working sessions in Lima and City of Guatemala, the network hosted several meetings with Andean key actors in order to diffuse the content of the report. Between October 28th and November 5th 1972, at the occasion of the Lawyer's Congress of the Andean Group, Felipe Salazar Santos, coordinator of the Junta and one of the drafters of the report, was in charge of presenting the draft and reaffirming the need for an Andean judicial organ before the legal community (Salazar Santos 1973b). The congress focused on issues related to law and integration, the role of lawyers in the integration process, and of course the establishment of a jurisdictional organ for the Cartagena Agreement (INTAL 1973b: 179). Only few days later, from November 20th to 24th, INTAL sponsored a seminar at a Colombian University, the Colegio Mayor de Nuestra Senora del Rosario. The topic hinged around "Legal aspects of economic integration" and the presentations focused on the new Andean legal system and the European experience with its Court of Justice. Among the Andean presenters were noted participants of the working group: Felipe Salazar Santos and Gustavo Fernandez Saavedra, both Junta officials, Felix Peña and Francisco Villagrán Kramer from INTAL, Jacobo Schaulson and Jaime Vidal Perdomo who had represented Chile and Colombia in the initial meeting; and finally, presenting the European experience: Jean Victor Louis, professor for European law at Brussels University, and Michel Gaudet, former director of the EC's Legal Service (INTAL 1973a: 178).

Between 1973 and 1979, INTAL consistently used its periodicals for the diffusion of the ACJ project and the convenience of legal integration. This was made especially through the journal Derecho de la Integración (see e.g. INTAL 1975: 5-7) and penned by the members of the network. Notably Pierre Pescatore (1973, 1974a, 1974b, 1977), Francisco Orrego Vicuña (1974, 1975, 1977), Felipe Salazar (1978), and Felix Peña (1979). In addition, the journal started a series containing relevant rulings of the ECJ (1976a, 1976b, 1977, 1978a, 1978b). This effort of diffusion has not many parallels in the history of international organizations in the region. ${ }^{22}$

\section{Conditions for the Action of Networks: Using Windows of Opportunities ${ }^{23}$}

In 1979 the final report of the Andean Junta was presented as a formal proposal to be adopted by the Andean Commission. It becomes difficult to gauge the exact developments in those meetings and sessions. There are rare accounts of them. Some of them suggest that the proposal unfolded rounds of deep discussion, followed by hard bargaining and deliberation. Among the town criers is founding Judge Carlos Sáchica. He describes the negotiation as follows:

22 My claim contradicts Karen Alter's account of the establishment of Andean jurisprudence. Alter suggests that in comparison with the European Court of Justice, there were no significant Andean Advocacy movement that could have underpinned ECJ-style case law (Alter 2008). I argue that without significant networks, the ACJ would not have been transplanted in the first place.

23 I am grateful to an anonymous commentator for suggesting this expression. 
"The negotiation was slow. Many meetings of experts coming from member states tweaked the original proposal, and along lengthy debates it acquired the tenets that distinguish the Courts from its undeniable model: the Court of Justice of the European Communities." (Sáchica 1985a: 13)²4

Another account consistent with the deliberation approach is Zelada Castedo (1985), who explains the long time that was necessary to approve the statutes for the $A C J$, this is, eight years, with the assumption that preliminary work as well as intergovernmental negotiations that concluded with the Commission's approval were especially profound and the agreement was the consequence not of improvisation, but of much reflection and consideration. ${ }^{25}$ However, in a later passage, Zelada Castedo admits that there had been a quick consensus about the organization and competencies of the Court. Apparently any eventual changes incorporated into the report's proposal - especially those motivated by the member states - were not substantial, calling into question whether the outcome was the product of such hard deliberation. ${ }^{26}$

As a matter of fact, the final proposal approved by the Commission included all the features that the European Court of Justice became noted for: an annulment procedure, a non-compliance procedure, a procedure of preliminary rulings, and the principle of direct applicability of Andean law. In other words, the final outcome is consistent with the work of the INTAL-Junta network, and there are not any significant changes that could bolster the claim of an approval based on deliberation. Rather, it seems to be that the final proposal's approval in 1979 followed a similar path of the preliminary report in 1972: a swift confirmation of what had been done by the Junta, with lip service being paid to an image of hard negotiations and confrontation between national representatives.

The next part offers the evidence that upholds such claims. It is based on reports published in the same years by the Institute for the Integration of Latin America and the Caribbean, INTAL (see Orrego Vicuña 1971, 1972).

24 "La negociación fue lenta. Varias reuniones de expertos de los países miembros perfeccionaron la propuesta original, y en los largos debates adquirió los matices que distinguen al Tribunal de su innegable modelo: la Corte de Justicia de las Comunidades Europeas" (translation of author).

25 "El prolongado lapso transcurrido entre las primeras iniciativas y la suscripción del Tratado, autoriza a pensar que tanto los trabajos preliminares como las negociaciones intergubernamentales fueron amplios y profundos, y que el acuerdo final no fue resultado de la improvisación sino, mas bien de una larga reflexión." (Zelada Castedo 1985: 127)

26 "Por lo visto, la concepción sobre la naturaleza, competencias y organización del órgano jurisdiccional propuesto, surgió relativamente pronto. A partir de la conclusión del citado informe y de las respectivas bases para un tratado preparadas por la Junta, o sea después de 1972, los trabajos posteriores se redujeron a un afinamiento de las ideas originales, después de confrontarlas, seguramente, con el pensamiento de los gobiernos. Las discrepancias entre este y aquellas, aparentemente, no fueron sustanciales, por lo cual habría que indagar por otro lado sobre las causas que dilataron el proceso de negociación y suscripción de Tratado." (Zelada Castedo 1985: 131) 


\section{Contesting the Governments' Control over the Integration Process}

\subsection{The Case of the Chilean Parliament}

The Cartagena Agreement is an international treaty; certainly a very special one, but still an international treaty. Therefore, it is interesting to note that it was implemented by means of executive decrees only, meaning, with no participation of parliaments or any other control organs (Orrego Vicuña 1970: 48). The recurrent doctrinal justification for this novelty has been so far that the Cartagena Agreement derives from LAFTA's Treaty of Montevideo, and considering the fact that member states had already transferred the necessary powers to this framework treaty (tratado marco), they had implied powers to accelerate the process through subnational agreements (Villagrán Kramer 1973).

Parallel to the signature and approval of the Cartagena Agreement, the Chilean parliament was challenging the government's powers to control the integration process. The Andean Group had envisioned a multilateral financial mechanism that would foster common investment projects in the region. The Corporación Andina de Fomento (CAF) was shaped as an international corporation, whose main shareholder would be the member states, along with some minor participation of private investors. Its initial capital entailed over US \$100 Million (Salazar Santo 1973: 3). Despite the active support of the signing governments, the CAF, as well as its statutes, were formally forged outside the Cartagena Agreement. This was a circumstance that would not remain unnoticed to the Chilean Senate. That same year 1969, the statutes of the CAF were being discussed in the Chilean Parliament, specifically the Senate, as an ordinary international treaty. Some representatives that were skeptical of the neutrality of the CAF, severely questioned a rule that allowed the shareholders assembly to change the very statutes that were being discussed. It was suggested that this faculty would render the parliamentary discussion sterile. Moreover, the underlying fear was that the governments would sell their share in CAF to private investors, eroding national control over the new multilateral financial mechanism. Alerted by the government about these growing difficulties (Orrego Vicuña 1970: 59), the Andean Commission tried to issue a statement in the sense that member states could only sell some of their shares in CAF to private actors if the Andean governments agreed unanimously (Andean Commission 1970; see also CAF 1970). In spite of the fact that these preventive measures addressed all the concerns and points raised by the Chilean Senate, the effect it caused did not go unnoticed. The Senate demanded that the government include a "declaration" 27 in the statues of $\mathrm{CAF}$, through which any decision taken by the organs of CAF that touched these sensitive points required the approval of the Chilean Parliament. In addition, all decisions taken by CAF organs had to comply with Chilean law. Although it was highly unlikely that any organ of CAF would issue any decisions as provocative as suggested, the Senate had managed to contest the Governments control over the integration process.

\subsection{Colombia and its Supreme Court}

The Colombian Supreme Court was a main protagonist in a short saga that challenged the government's authority to control the pace of regional integration. In 1971, an individual presented an action of

27 Approved 23.06.1970. Its text was disclosed in the newspaper "El Mercurio", in its edition of 27.06.1970, p. 15 (cited by Orrego Vicuña 1970: fn. 54). 
unconstitutionality before the Supreme Court. The argument was that the incorporation of the Cartagena Agreement by the Colombian government had circumvented the parliament, and therefore the relevant executive decree should be invalidated (cf. Colombian Government 1969). In its ruling the Supreme Court assumed that the Cartagena Agreement was an ordinary international treaty, and not a derivative of the Treaty of Montevideo. Therefore, it stated that the Colombian Government had indeed violated the regular proceeding for incorporating international law into the domestic order (Colombian Supreme Court 1971). However, in the same ruling the Court refused to annul the executive decree, based on the Colombian legal tradition that gives precedence to international commitments whenever the government has given its formal agreement. The Court explained that even if the Colombian government infringed national rules by avoiding national control by the legislator, it could not break its international commitments. As a consequence, the action was rejected and the Cartagena Agreement was regarded as valid. Nevertheless, the flip side of this ruling was that this legal tradition did not apply to decisions made by Andean organs. Therefore, the Court left the door open for Andean secondary law to be subjected to parliamentary approval if it was to be valid in Colombia (Orrego Vicuña 1972: 52).

If one reads the Junta's report against the development that took place during the debate in the Chilean Senate and the Colombian Supreme Courts, the swift procedure for approving the proposal makes sense. A control mechanism necessary to check the activities of community organs figures very prominently in the report: the annulment procedure (JUNAC 1972, Chapter V). This supposedly urgent need did not figure at all in the preparatory work; neither did it in the profuse literature of INTAL or in any other integration scheme (Orrego Vicuña 1971: 134). It is perfectly plausible, however, if we remember that governments were having severe difficulties with their domestic control organs. As the evidence shows, the Chilean Senate and the Colombian Supreme Court doubted that Andean organs would exercise self-restraint and used the argument to assume the control of legality of secondary law. Therefore, the creation of a court with powers to control legality of Andean acts and nullify them if necessary, would terminate the exhausting debates at national level, and shift the oversight function to the supranational level. In addition, the Junta adapted its language and incorporated functional vocabulary like "further harmonization, stage of progress, uniform interpretation", (see JUNAC 1976, especially: 22, 73, 76f). This strategy might have prevented the discussion over the proposal to become a salient one. In fact, it was "regarded as just one among many proposals" (Ferris 1979: 99).

It remains unclear who came up with this strategy, the governments representatives' themselves, the Junta, or the INTAL network. According to the evidence found, the first time that this idea appears in written is a brief passage in the final protocol of a summit of the Commission. This would lead to the thought that national governments initiated this project. However, it can be inferred from consistent work of the European-Andean network that this was the pioneering force. The fact that the proposal included not only control mechanisms needed by the governments, but all the procedures of the ECJ, suggests that the project was conceived to go much further than envisioned by the member states. The network only needed a window of opportunity to materialize its policy goals.

As a consequence, a Treaty Establishing the Andean Court of Justice was signed in 1979, and ratified by the last member states in $1983 .^{28}$

28 That it took so long for this treaty to be ratified by the member states is convincingly explained by Marwege, based on the objection - at national level - of the Venezuelan Constitutional Court (Marwege 1995). 


\section{Expanding the Network: Bringing the Judges in}

Scholars have recently suggested that once established the judges of the Andean Court of Justice began explicitly resorting to case law of the ECJ in their own rulings, as they incorporated doctrines of direct effect and supremacy of Andean law, by means of a procedure of preliminary rulings. ${ }^{29}$ All these were institutions and concepts modeled on the European Court of Justice, European case law, and the European procedure of preliminary rulings. ${ }^{30}$ The European legal vocabulary was adopted with the result of an isomorphic technical jargon identical - formally at least - to the EC's. ${ }^{31}$

There are not many attempts to explain why a court would be so open to cross-fertilization. Latin American legal scholars have justified this incorporation on normative grounds, that these types of rulings are a natural legal development when supranational courts begin their work. This means that every supranational court would tend automatically to hand down similar rulings because it is immanent to supranational courts to follow the compelling nature of community law (for a critique of such arguments, see Saldías 2008).

Karen Alter suggests another possibility: it was the personal engagement of a few judges. She mentions one in particular, Judge Galo Pico Mantilla, who was the president of the Court when the doctrines of supremacy and direct effect were incorporated (Alter 2008: 26). Similarly, but in a general way, AnneMarie Slaughter views the processes of judicial cross-fertilization as the product of judicial globalization. In her view, judges talk to each other in a process of intellectual exchange and mutual learning that leads to courts using the ideas of their peers (Slaughter 1998, 2000, 2003).

Evidence suggests though, that professional networks are far more relevant than previously assumed. The incorporation of the ECJ's core repertoire into Andean case law can be traced back to the same network that procured its transplantation. This explanation is more convincing than the previously mentioned views.

The initial cadre of Andean judges was appointed in January 1984, in a meeting that took place in Quito (Gabaldón Márquez 1985: 111). Among the new magistrates, there was Luis Carlos Sáchica, José Guillermo Andueza, Estuardo Hurtado Larrea, and the Court Secretary Iván Gabaldón Márquez. The following year, in 1985, the four of them were reunited by INTAL, and under the lead of Alberto Zelada Castedo, the institute's head of the legal department, the first comprehensive monograph on the Andean Court of Justice was penned (BID-INTAL 1985). This coordinated work had the potential of massively influencing future case law, since it was published in the time between the date of enactment of the Treaty establishing the Court (19 May 1983), and the first ruling in 1987.

29 By the time the Andean Court took on its activities, milestones of European case law were already in place, for example case 3/62 Commission v. Luxembourg [1963] ECR 445; case 26/62 Van Geld \& Loos [1963] ECR 1; case 6/64 Costa ENEL [1964] ECR 585; case 6/72 Continental Can [1973] ECR 215; case 8/74 Dassonville [1974] ECR 837.

30 Explicit references to European case law are made, for example, in case 2-IP-88 citing the Costa v. ENEL, as well as Simmenthal, at page 2, and case 39/70 Norddeutsches Vieh- und Fleischkontor GmbH v Hauptzollamt HamburgSt. Annen [1974] ECR 899 at page 4 (see ruling ACJ 2-IP-88).

31 I discuss the differences between Andean and European case law elsewhere, as well as the implications for legal integration (Saldías 2009). 
In the introductory part of the monograph, INTAL's director Juan Vacchino acknowledges the importance of diffusing "the competencies, the organization, and functioning of this organ", as well as the close collaboration between the institute and the Junta in the 1970s (Vacchino 1985: 3). In the light of network analysis, there are two striking aspects in regard to this work:

a) All articles explicitly refer to key aspects of Andean law that had been discussed in the Junta's final report. These community-enhancing features were the doctrines of direct effect, supremacy, and the procedure of preliminary rulings. (Sáchica 1985a: 8, 13, 24; Andueza 1985a: 33, 41; Hurtado Larrea 1985: 70; Andueza 1985b: 97; Zelada Castedo 1985: 139). The content substantially reflects the ideas of the working group that prepared the final report.

b) Key European authors, who were part of the working group, monopolize the European scholarly influence. For the newly sworn-in Andean judges, they seem to represent the gateway to European Community law. Pierre Pescatore, Jean Victor Louis, Maurice Lagrange and Michel Gaudet become point of reference whenever the ECJ is used as object of comparison (Andueza 1985a: 42, 5; Sáchica 1985b: 52; Andueza 1985b: 109; Zelada Castedo 1985: 148, 56, 59). ${ }^{32}$

Following this publication, Andean judges continued diffusing the ideas on supranational law and the newly established ACJ (e.g. Andueza 1986). There was plenty of time for this preparatory phase, since it took the ACJ four years to hand down its first rulings, allegedly due to an initial lack of cases. ${ }^{33}$ Although the number of articles or books published by the judges was modest in comparison to the European workload, it was fully consistent with the project endeavored by the working group that assisted the Junta. A comparison between the final report, and the work described so far, shows striking similarity. Newcomers to the court, like Nicolás de Piérola, also continued the process of diffusion (de Piérola 1987). In fact, de Pierola presided the Court when a noted ruling was handed down, reaffirming the doctrines of supremacy in May 1988 (2-IP-88). A year earlier, the doctrines had been incorporated in ruling 1-IP-87, when the court was presided by the Ecuadorian judge Galo Pico Mantilla. Karen Alter rightly suggests, that it might have been him, who penned that ruling. It is important to add, however, that Pico Mantilla had not been neutral in regard to the process of establishment of the Court.

"A gentleman-lawyer who was once Secretary of the Minister of Industry and Ambassador to Venezuela, Mantilla sought to emulate the European legal integration strategy. Mantilla was committed to Andean integration as an end in itself, having been a participant in negotiations involving Andean integration and in the negotiations that led to the founding of the Andean Court." (Alter 2008: 26; emphasis added by author)

Although Alter's assessment of the contribution of Judge Pico Mantilla is very plausible if the analysis starts with the first ruling, the doctrinal content related to supremacy can be found earlier, namely in

32 To be sure, there are references to other European scholars who did not participate in the network, but these are scholars of constitutional and international law rather than European law; for instance Hans Kelsen, Jorge Rodriguez Zapata, Henri Wagnon Charles Rousseau. The only exception is Jean de Richmond, whose work in French is cited by Andueza (Andueza 1985b: 99).

33 Karen Alter suggests that member states refused to authorize the Andean legal secretariat to proceed with cases (Alter 2008: 24). 
the working group on the establishment of the ACJ. The Court does not acknowledge this explicitly, but in both rulings mentioned above, one can find in the preliminary considerations ${ }^{34}$ cross references to EC-law when it comes to introduce the issue of supremacy and direct effect, ${ }^{35}$ as well as the method of teleological interpretation within the procedure of preliminary rulings. ${ }^{36}$

In sum, the network that worked on the transplantation of the ECJ into the Andean region was far more relevant than scholars have previously thought. It is a small, dense web of relations that was able to use certain conditions in order to achieve their goal of establishing a supranational court of justice. However, their influence does not stop there. As this research has shown, the action of professional networks can shape the content of the initial case law of the court they were advocating for. Therefore, this last finding challenges some accounts of diffusion of law based on judicial dialogues and judicial cross-fertilization.

\section{Conclusion}

The data that has been collected so far with the help of the network approach shows that trans-regional networks indeed existed by the time of the transformation of the Andean Pact and the incorporation of the ECJ model. These networks play a role far more significant than scholarship has assumed so far.

Contrary to accounts that assume complex decisions to be the product of intense deliberation and bargaining, the establishment of the Andean Court of Justice can be traced back to a think tank and the organized work of a professional advocacy network: the INTAL-Junta network. It is difficult to label the INTAL network as a pure epistemic community or an advocacy coalition. In the narrative above, features of both ideal types can be recognized. This testifies to the fact that theories on those kind of communities are ideal tools that help us understand the world, and do not necessarily mirror reality.

Using favorable conditions of domestic contestation, a "window of opportunities" the network aligned itself with member state's governments along with a technical discourse, positioning themselves as their agents. Once accepted as agents, they used their epistemic resources to accommodate governments' preferences and convince them to break with established doctrines of state sovereignty. The incorporation of the annulment procedure at supranational level corresponds to this strategy. At the same time, the new agent incorporates its own policy agenda; for the INTAL network this was a full-blown court inspired in the ECJ. There are implications for theories of European integration and diffusion. First, the establishment of new

34 Known as considerandos in Spanish legal jargon.

35 "El Tribunal de Justicia de las Comunidades Europeas, en las sentencias antes citadas, ha afirmado la preeminencia absoluta del derecho comunitario sobre el interno, tesis que resulta ser tambien applicable en el ordenamiento juridico de la integracion andina conforme antes se indico" (Andean Court of Justice 1988).

36 "En cuanto a los metodos de interpretacion que debe utilizar el Tribunal, ha de tenerse presente la realidad y caracteristica esenciales del Nuevo Derecho de la Integracion y la importante contribucion que en esta material tiene ya acumulada la experiencia europea, sobre tod por el aporte de la jurisprudencia de la Corte de Justicia, Tribunal unico de las Comunidades Europeas en la aplicacion de este derecho, que se esta haciendo constantemente en beneficio de la construccion comuntaira, sin perder de vista el fin permanente de la norma. Por estas consideraciones corresponde el empleo preferente de los metodos de interpretacion llamados 'funcionales', como los metodos sistemativos y de interpretacion teleological [...]" (Andean Court of Justice 1987). 
institutions and the shift of decisional powers to the center of the organization were provoked by a concerted advocacy coalition with the complicity of member states against national actors that had emerged as alternative gatekeepers of Andean integration. In Europe, neo-functionalists observed how self-interested private actors challenged their governments and shifted their loyalties towards the Community. To be sure, if this chapter of Andean integration should become a challenge to neo-functionalist assumption, it will certainly need more evidence. Nevertheless, it is interesting to note that the technical discourse used by the network takes much inspiration from neo-functionalist thinking. Second, it took much agency in order to successfully transplant the ECJ into the Andean region. Functional requirements of the common market were not enough. This speaks against arguments of automaticity in regional integration.

In regard to network theories, especially advocacy coalitions, the Andean case allows to make some claims. The theory on advocacy coalitions is confirmed in its assertion that it is much more decisive for policy outcomes to determine who gets to give the relevant advice. Once the adviser has been chosen, the content will largely depend on actors' background and socialization. Moreover, some professional advocacy coalitions use their special knowledge in order to accommodate the preferences of important stakeholders, like governments. Once the networks become an agent, they can use their epistemic resources to propose solutions that are consistent with both, the stakeholder's needs and their own policy agenda. In the Andean case the INTAL network framed the problems as "legal matters" and proposed a strong functional pro-integrationist policy agenda. Consistent with network theories, technical knowledge can be presented as neutral and subject to scientific scrutiny only.

The last claim is that networks can significantly increase their efficacy by actively communicating their policy program. The coordinated communicational strategy of the INTAL-Junta network appears as decisive for the acceptance of the Court and the subsequent reception of the ECJ's doctrine of direct effect and supremacy. 


\section{Literature}

Alter, Karen 2008: Jurist Advocacy Movements in Europe and the Andes. How Lawyers Help Promote International Legal Integration, in: Center on Law and Globalization Research Paper 08/05, 1-34.

Andean Commission 1970: Segundo Período de Sesiones Ordinarias, 9-13 March, Lima.

Andean Commission 1971: Sexto Período de Sesiones Extraordinarias, Acta Final, 9-18 December, Lima.

Andean Commission 1972: Decimo Periodo de Sesiones Extraordinarias de la Comision, COM/XE-acta final.

Andean Court of Justice 1987: Ruling 1-IP-87, Aktiebolget VOLVO vs. Colombia, 3 December.

Andean Court of Justice 1988: Ruling 2-IP-88, Daimler Benz AG vs. Colombia, 24 May.

Andueza, José Guillermo 1985a: La Aplicación Directa del Ordenamiento Jurídico del Acuerdo de Cartagena, in: BID-INTAL (ed.): El Tribunal de Justicia del Acuerdo de Cartagena, Buenos Aires, 27-45.

Andueza, José Guillermo 1985b: La Interpretación Prejudicial y el tribunal de Justicia del Acuerdo de Cartagena, in: BID-INTAL (ed.): El Tribunal de Justicia del Acuerdo de Cartagena, Buenos Aires, 83-109.

Andueza, José Guillermo 1986: El Tribunal del Pacto Andino, Quito, Ediciones del Tribunal de Justicia del Pacto Andino.

Balassa, Bela 1972: El segundo decenio para el desarrollo y la integración económica regional, in: Revista de la Integración 11/Mayo, 5-19.

Bayá Claros, María de la Cruz 2004: Derecho y Procesos de Integración, Cochabamba.

Berkowitz, Daniel/Pistor, Katharina/Richard, Jean-Francois 2003: The Transplant Effect, in: American Journal of Comparative Law 51/1,163-204.

Börzel, Tanja 1997: What's So Special About Policy Networks? An Exploration of the Concept and Its Usefulness in Studying European Governance, in: European Integration online Papers (EloP) 1/16.

Börzel, Tanja A./Risse, Thomas 2009: The Transformative Power of Europe. The European Union and the Diffusion of Ideas, in: KFG Working Paper No. 1, May 2009, Freie Universität Berlin.

BID-INTAL (ed.) 1985: El Tribunal de Justicia del Acuerdo de Cartagena, Buenos Aires.

Camacho Omiste, Edgar 2001: El Marco Constitucional y el Principio de la Supranacionalidad, in: Secretaría General de la Comunidad Andina (ed.): Integración y Supranacionalidad: Soberanía y Derecho Comunitario en los Países Andinos, Lima.

Colombian Government 1969: Executive Decree № 1245, 08 August.

Colombian Supreme Court 1971: ruling of 26 July, in: Derecho de la Integración 10/abril, 160-180.

Comunidad Andina, Secretaría General (ed.) 2001: Integración y Supranacionalidad: Soberanía y Derecho Comunitario en los Países Andinos, Lima.

Corporación Andina de Fomento (CAF) 1970: Primera Asamblea de la Corporación Andina de Fomento, Caracas 8-9 junio.

Craig, Paul/de Búrca, Gráinne 2008: EU Law. Text, Cases, and Materials (4th edition), New York.

da Cruz Vilaça, José Luis/Sobrino, José Manuel 1996: Del Pacto a la Comunidad Andina: El Protocolo de Trujillo de 10 de marzo de 1996 ¿simple reforma institucional o profundización en la integración subregional?, in: Gaceta Jurídica de la CE y de la Competencia, D/26, 83-138.

Dehousse, Renaud 1998: The European Court of Justice: the politics of judicial integration, New York.

de Piérola, Nicolás 1987: The Andean Court of Justice, in: Emory Journal of International Dispute Resolution 2, 11-38. 
DiMaggio, Paul/Powell, Walter 1983: The iron Cage Revisited: Institutional Isomorphism, and Collective Rationality in Organizational Fields, in: American Sociological Review 48/2, 147-60.

Díaz Barrado, Cástor 1999: Iberoamérica ante los Procesos de Integración: Una aproximación general, in: XVIII Jornadas de la Asociación Española de Profesores de Derecho Internacional y Relaciones Internacionales, Boletín Oficial del Estado, Madrid.

Dreyzin de Klor, Adriana/Uriondo de Martionoli, Amalia 1996: Derecho internacional privado y de la integración regional. Fuentes convencionales, Buenos Aires.

Dromi San Martino, Laura 2002: Derecho Constitucional de la Integración, Facultad de Derecho, Universidad Complutense, Madrid.

Ekmekdjian, Miguel Ángel 1994: Introducción al derecho comunitario latinoamericano con especial referencia al Mercosur, Buenos Aires.

Emmes, Manfred/Mols, Manfred 1993: Integration, Kooperation und Konzertation in Lateinamerika, in: Mols, Manfred/Wilhelmy von Wolff, Manfred/Gutiérrez, Hernán (eds.): Regionalismus und Kooperation in Lateinamerika und Südostasien im Zusatz ein politikwissenschaftlicher Vergleich, Münster.

European Court of Justice 1976a: CEE: sentencias de la Corte de Justicia, in: Derecho de la Integración 21/ Marzo, 190-222.

European Court of Justice 1976b: CEC: sentencias de la Corte de Justicia (II parte), in: Derecho de la Integración 22-23/Julio-Noviembre, 120-153.

European Court of Justice 1977: Sentencias de la Corte (IV parte), in: Derecho de la Integración 25-26/ Noviembre, 143-150.

European Court of Justice 1978a: Sentencias de la Corte (V parte), in: Derecho de la Integración 27/Marzo. 189-212.

European Court of Justice 1978b: Sentencias de la Corte (VI parte), in: Derecho de la Integración 28-29/ Noviembre, 162-168.

Ferris, Elizabeth 1979: National Political Support for Regional Integration: The Andean Pact, in: International Organization 33/1, 83-104.

Gabaldón Márquez, Iván 1985: Algunos comentarios sobre el estatuto del Tribunal de Justicia del Acuerdo de Cartagena, in: BID-INTAL (ed): El Tribunal de Justicia del Acuerdo de Cartagena, Buenos Aires.

Haas, Ernst 1972: El estudio de la integracion regional: reflexiones acerca de la alegría y la angustia de preteorizar, in: Revista de la Integración 10/Mayo, 85-139.

Haas, Peter 1992: Introduction: Epistemic Communities and International Policy Coordination, in: International Organization 46/1, 1-36.

Heartley, Trevor 1996: The European Court, Judicial Objectivity and the Constitution of the European Union, in: Law Quarterly Review 112/January, 95-109.

Helfer, Laurence/Alter, Karen/Guerzovich, Florencia 2009: Islands of Effective International Adjudication. Constructing an Intellectual Property Rule of Law in the Andean Community, in: Law \& Economics Research Paper No. 8/22, Northwestern University School of Law.

Horwitz, Morton 2009: Constitutional Transplants, in: Theoretical Inquiries in Law, 10/2, Article 8, 535560.

Hummer, Waldemar 1979: Regionale Integrationsideologie und innerstaatliche Legitimationsbedürfnisse, in: Benecke, Dieter/Domitra, Michael/Mols, Manfred (eds.): Integration in Lateinamerika, Beiträge des Symposiums der Arbeitsgemeinschaft Deutsche Lateinamerika-Forschung vom 08.10.11.1979, München.

Hurtado Larrea, Eduardo 1985: Los Incumplimientos y la Acción Asignada a la Competencia del Tribunal, in: BID-INTAL (ed): El Tribunal de Justicia del Acuerdo de Cartagena, Buenos Aires. 
Institute for the Integration of Latin America and the Carribean 2010: General Information, in: http://www. iadb.org/intal/detalle_articulo.asp?idioma=ENG\&aid=490\&cid=206\&nivel; 18 August 2010.

INTAL 1971: Editorial. La idea de conflicto y el ordenamiento jurídico e institucional de la integración económica, in: Revista de la Integración 8/Abril, 5-6.

INTAL 1972: Estudio sobre procedimientos para solucionar conflictos, in: Derecho de la Integración 11/ Octubre, 121-131.

INTAL 1973a: Colombia: Seminario sobre aspectos jurídicos de la integracion, in: Derecho de la Integración 12/Marzo,178.

INTAL 1973b: Primer Congreso de Abogados del Grupo Andino, in: Derecho de la Integración 12/Marzo, 179-181.

INTAL 1975: Editorial. El aporte del derecho económico al derecho de la integración, in: Derecho de la integración 18-19/Marzo/Julio, 5-7.

INTAL 1976a: CEE: sentencias de la Corte de Justicia, in: Derecho de la Integración 21/Marzo, 190-222.

INTAL 1976b: CEC: sentencias de la Corte de Justicia (II parte), in: Derecho de la Integración 22-23/JulioNoviembre, 120-153.

INTAL 1977: Sentencias de la Corte (IV parte), in: Derecho de la Integración 25-26/Noviembre, 143-150.

INTAL 1978: Sentencias de la Corte (V parte), in: Derecho de la Integración 27/Marzo. 189-212.

INTAL 1978: Sentencias de la Corte (VI parte), in: Derecho de la Integración 28-29/Noviembre. 162-168.

Jenkins-Smith, Hank/Sabatier, Paul 1994: Evaluating the Advocay Coalition Framework, in: Journal of Public Policy 14/2, 175-203.

Junta del Acuerdo de Cartagena (JUNAC) 1972: Informe de la Junta sobre el establecimeinto de órgano jursidiccional del Acuerdo de Cartagena, COM/VI-E, Lima.

Junta del Acuerdo de Cartagena (JUNAC) 1973: Informe de la Junta sobre el establecimiento de un órgano jurisdiccional del Acuerdo de Cartagena, in: Derecho de la Integración 13/Julio, 135-150.

Junta del Acuerdo de Cartagena (JUNAC) 1979: Evaluación del Proceso de Integración 1969-1979 Grupo Andino, Lima.

Junta del Acuerdo de Cartagena (JUNAC) 1983: Sobre el cumplimiento de los compromisos derivados del Acuerdo de Cartagena y de las Decisiones de la Comisión, Lima.

Kirov, Jani 2009: Foreign Law Between „Grand Hazard“ and Great Irritation: The Bulgarian Experience After 1878, in: Theoretical Inquiries in Law, 10/2, Article 14.

Lagrange, Maurice 1968: La interpretación unitaria del derecho de las Comunidades Europeas: aspectos de la interpretación prejudicial, in: Derecho de la Integración 3/Octubre, 51-80.

La Porta, Rafael/López de Silantes, Florencio/Shleifer, Andrei/Vishny, Robert 1998: Law and Finance, in: Journal of Political Economy 106, 1113-1155.

Likhovski, Assaf 2009: Argonauts of the Eastern Mediterranean. Legal Transplants and Signaling, in: Theoretical Inquiries in Law, 10/2, 619-651.

Legrand, Pierre 1997: Against a European Civil Code, in: Modern Law Review 60/1, 44-63.

Mahoney, Paul G. 2001: The Common Law and Economic Growth. Hayek Might be Right, in: Journal of Legal Studies 30/2, 503-525.

Marwege, Renata 1995: Der Andengerichtshof. Das Rechtsschutzsystem des Andenpaktes mit vergleichenden Bezügen zum Recht der Europäischen Gemeinschaft, Berlin.

Mols, Manfred 1993: Zur Genese und Begründungslogik des modernen internationalen Regionalismus in Lateinamerika, in: Mols, Manfred/Wilhelmy von Wolff, Manfred/ Gutiérrez, Hernán (eds.): Regionalismus und Kooperation in Lateinamerika und Südostasien. Ein politikwissenschaftlicher Vergleich, Münster. 
Nelken, David/Feest, Johannes (eds.) 2001: Adapting Legal Cultures, Oxford.

Nye, Joseph 1969 Integración regional comparada: concepto y medición, in: Revista de la Integración 5/ Noviembre, 50-86.

Orrego Vicuña, Francisco 1970: La incorporación del ordenamiento jurídico subregional al derecho interno. Análisis de la práctica chilena, in: Derecho de la Integración 7/Octubre, 42-67.

Orrego Vicuña, Francisco 1972: La incorporación del ordenamiento jurídico subregional al derecho interno. Análisis de la práctica y jurisprudencia de Colombia, in: Derecho de la Integración 11/Octubre, 39-60.

Orrego Vicuña, Francisco 1973: Contemporary International Law in the Economic integration of Latin America, in: Rideau, Joël (ed.): Les aspects juridiques de I'integration economique. Colloque de 1971, Sijthoff, Leiden.

Orrego Vicuña, Francisco 1974: La creación de un tribunal de justicia en el Grupo Andino, in: Derecho de la Integracion 15/Marzo, 31-46.

Orrego Vicuña, Francisco 1975: La adaptación de lo pactado a los cambios contextuales que inciden en un proceso de integración, in: Derecho de la Integración 20/Noviembre 37-46.

Orrego Vicuñan, Francisco 1977: Los presupuestos jurídicos de un proceso de integración económica efectivo, in: Derecho de la Integración 24/Marzo, 11-20.

Padilla, David 1979: The Judicial Resolution of Legal Disputes in the Integration Movements of the Hemisphere, in: Lawyers of the Americas 11/1, 75-95.

Paolillo, Felipe 1968: Reparticion de competencies y poderes entre la ALALC y los Estados miembros, in: Derecho de la Integracion 2/Abril 1968, 20-49.

Paolillo, Felipe/Ons-Indart, Carlos 1971: Estudio de los procedimientos de hecho utilizados para la solución de conflictos en la ALALC, in: Derecho de la Integración 9/ Octubre, 19-74.

Peña, Félix 1979: La experiencia instituconal de la integración económia de América Latina, in: Integración Latinoamericana 6/64, 27-32.

Peña, Félix 2010: Trayectoria, in: http://www.felixpena.com.ar/index.php?contenido=trayectoria; 18 August 2010.

Perotti, Alejandro 1999: Los tribunales comunitarios en los procesos de integración. El caso del Tribunal de Justicia de la Comunidad Andina, in: Revista Dikaion 8/Julio,186-241.

Perotti, Alejandro 2001: Algunas consideraciones sobre la Interpretación Prejudicial Obligatoria en el Derecho Andino, in: Revista Dikaion 16/11, 128-153.

Pescatore, Pierre 1967: Distribución de competenicas y de poderes entre los Estados miembros de las Comunidades Europeas, Derecho de la Integración 1/Octubre 108-152.

Pescatore, Pierre 1973: Derecho de la integración. Nuevo fenómeno en las relaciones internacionales, in: Publicaciones INTAL 74/Octubre, 1-105.

Pescatore, Pierre 1974a: La importancia del derecho en un proceso de integración económica, in: Derecho de la Integración 15/Marzo, 11-21.

Pescatore, Pierre 1974b: Las exigencias de la democracia y la legitimidad de la Comunidad Europea, in: Derecho de la Integración 17/Noviembre, 45-54.

Pescatore, Pierre 1977: El ejecutivo comunitario: justificación del cuatripartismo instituido por los tratados de Paris y Roma, in: Derecho de la Integración 25-26/Noviembre 53-62.

Rico Frontaura, Víctor 2001: El Derecho de la Integración en la Comunidad Andina, in: Secretaría General de la Comunidad Andina (ed.): Integración y Supranacionalidad: Soberanía y Derecho Comunitario en los Países Andinos, Lima.

Rideau, Joel (ed.) 1973: Les Aspects juridiques de l'intégration économique. Académie de droit inetrnational de La Haye, Colloque 1971, Sijthoff, Leiden. 
Ruggie, John 1975: International Responses to technology, in: International Organization 29/Summer, 56970.

Sáchica, Luis Carlos 1985a: El Ordenamiento Jurídico Andino y su Tribunal de Justicia, in: BID-INTAL (ed.): El Tribunal de Justicia del Acuerdo de Catagena, Buenos Aires.

Sáchica, Luis Carlos 1985b: La Acción de Nulidad en el Ordenamiento Jurídico Andino, in: BID-INTAL (ed.): El Tribunal de Justicia del Acuerdo de Catagena, Buenos Aires.

Salazar Santos, Felipe 1973a: The Andean Group: Fact or Fiction?, in: American Bar Association, Conference on "Current Legal Aspects of Doing Business in Latin America. The New Challenge of Latin American Nationalism to Foreign Investment - Present and Future", 4-5 May 1973, New York, United States of America.

Salazar Santos, Felipe 1973b: Acuerdo de Cartagena: aspectos jurídicos, in: Derecho de la Integración 13/ Julio, 150-6.

Salazar, Felipe 1978: Solución de conflictos en organizaciones interestatales para la integración económica y otras formas de cooperación económica, in: Derecho de la Integración 28-29/Noviembre, 1134.

Saldías, Osvaldo 2007: Supranational Courts as Engines of Disintegration. The Case of the Andean Community, in: Berliner Arbeitspapiere zur Europäischen Integration 5/October, 1-33.

Saldías, Osvaldo 2008: Comparative Community Law: Latin American Scholarship on Regional Integration and the Peril of Legal Functionalism, in: UCLA Pacific Basin Law Journal, 26/1, 51-71.

Saldías, Osvaldo 2009: Supranational Courts as Agents of Regional Integration. The ECJ and the ACJ in Comparison. Unpublished dissertation, Freie Universität Berlin.

Schmitter, Philippe 1969: La dinámica de contradicciones y la conducción de crisis en la integración centroamericana. Revista de la Integración 5/November, 87-151.

Slaughter, Anne-Marie 1998: Court to Court, in: The American Journal of International Law 92/4, 708-12.

Slaughter, Anne-Marie 2000: Judicial Globalization, in: Virginia Journal of International Law 40, 1103-24.

Slaughter, Anne-Marie 2003: A Global Community of Courts, in: Harvard International Law Journal 44/1, 191-219.

Sobrino, José Manuel 2001: Derecho de Integración, Marco Conceptual y Experiencia de la Unión Europea, in: Secretaría General de la Comunidad Andina (ed.): Integración y Supranacionalidad: Soberanía y Derecho Comunitario en los Países Andinos, Lima.

Söderbaum, Frederik 2008: Consolidating Comparative Regionalism: From Euro-centrism to Global Comparison, in: GARNET Annual Conference, University of Bordeaux, 17-19 September 2008.

Suárez Mejías, Jorge Luis 2001: Integración y Supranacionalidad en la Comunidad Andina: proceso decisorio, sistema jurisdiccional relación con los derechos nacionales. Unpublished Dissertation, Universidad Complutense de Madrid.

Tangarife, Marcel 2001a: La Supranacionalidad en el Constitucionalismo Latinoamericano: El caso de los Países Miembros de la Comunidad Andina, in: Secretaría General de la Comunidad Andina (ed.): Integración y Supranacionalidad. Soberanía y Derecho Comunitario en los Países Andinos, Lima.

Tangarife, Marcel 2001b: Sistema Jurisdiccional en el Proceso Andino, in: Secretaría General de la Comunidad Andina (ed.): Integración y Supranacionalidad. Soberanía y Derecho Comunitario en los Países Andinos, Lima.

Vacchino, Juan Mario 1985: Introducción, in: BID-INTAL (ed.): El Tribunal de Justicia del Acuerdo de Cartagena, Buenos Aires.

Villagrán Kramer, Francisco 1968: Los instrumentos legales de la integracion economica centroamericana, in: Derecho de la Integracion 3/Octubre, 36-58.

Watson, Alan 2000: Legal Transplants and European Private Law, in: Electronic Journal of Comparative Law, 44/December, in: http://www.ejcl.org/ejcl/44/44-2.html; 18 August 2010. 
Zafonte, Matthew/Sabatier, Paul 1998: Shared Beliefs and Imposed Interdependencies as Determinants of Ally Networks in Overlapping Subsystems, in: Journal of Theoretical Politics 10/4, 473-505.

Zelada Castedo, Alberto 1985: El Control de la Legalidad, la Solución de Controversias y la Interpretación Uniforme del Derecho Común en el esquema de Integración del Grupo Andino, in: BID-INTAL (ed.): El Tribunal de Justicia del Acuerdo de Cartagena, Buenos Aires.

Zucker, Lynne G. 1987: Institutional Theories of Organization, in: Annual Review of Sociology 13, 443-64.

Zweigert, Konrad/Kötz, Hein 1996: Einführung in die Rechtsergleichung (3rd ed.), Tübingen. 
The Kolleg-Forschergruppe - Encouraging Academic Exchange and Intensive Research

The Kolleg-Forschergruppe (KFG) is a new funding programme launched by the German Research Foundation in 2008. It is a centrepiece of the KFG to provide a scientifically stimulating environment in which innovative research topics can be dealt with by discourse and debate within a small group of senior and junior researchers.

The Kolleg-Forschergruppe "The Transformative Power of Europe" brings together research on European affairs in the Berlin-Brandenburg region and institutionalizes the cooperation with other universities and research institutions. It examines the role of the EU as promoter and recipient of ideas, analyzing the mechanisms and effects of internal and external diffusion processes in three research areas:

- Identity and the Public Sphere

- Compliance, Conditionality and Beyond

- Comparative Regionalism and Europe's External Relations

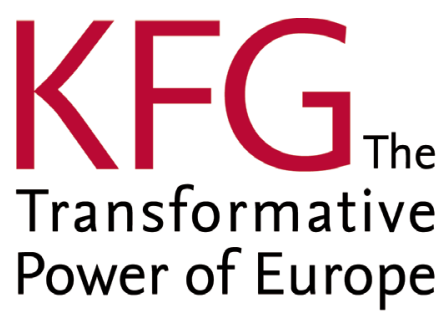

